SILVA, DMN; LIMA, RR; OLIVEIRA, FL; TEIXEIRA, LJQ MACHADO, LCA. 2018. Physical and chemical characterization of yacon tuberous roots produced at different altitudes and planting times. Horticultura Brasileira 36: 199-204. DOI: http://dx.doi.org/10.1590/S0102-053620180209

\title{
Physical and chemical characterization of yacon tuberous roots at different altitudes and planting times
}

\author{
Diego MN Silva; Raquel R Lima; Fábio L Oliveira; Luciano JQ Teixeira; Leonard CA Machado
}

Machado Universidade Federal do Espirito Santo (UFES), Alegre-ES, Brazil; diegoufvjm@yahoo.com.br; rah_lima@hotmail.com; fabiocapi@yahoo.com.br; luqteixeira@yahoo.com.br; nad.machado@yahoo.com.br

\begin{abstract}
The post-harvest quality of yacon tuberous roots produced at different altitudes and planting times were characterized in this study. The experiment was conducted in the South of Espírito Santo State in two locations, one at $837 \mathrm{~m}$ altitude and the other one at $113 \mathrm{~m}$ altitude. The experimental design, in each place, was randomized blocks with four replications, and the treatments consisted of three planting seasons: April (autumn), July (winter) and September (spring). After harvest of the tuberous roots, we evaluated $\mathrm{pH}$, titratable total acidity, moisture content, soluble solids, reducing sugars, crude fiber and ash, as well as color, hardness (maximum force recorded in the first penetration or compression cycle) and chewiness index (energy required to chew food, given by gumminess $\mathrm{x}$ elasticity). Tuberous roots grown at $837 \mathrm{~m}$ altitude, independent of planting times, presented higher soluble solids content and lighter juice, conferring better quality. However, at $113 \mathrm{~m}$ altitude, from April to July, the roots showed better quality, since it presents lower hardness and lighter juice.
\end{abstract}

Keywords: Smallanthus sonchifolius, post-harvest quality, instrumental coloration, sensorial traits.

\section{RESUMO}

Caracterização física e química de raízes tuberosas de yacon produzida em diferentes altitudes e épocas de plantio

Objetivou-se caracterizar a qualidade pós-colheita de raízes tuberosas de yacon produzidas em diferentes altitudes e épocas de plantio. O experimento foi conduzido no sul do Espírito Santo em duas localidades, a 837 e $113 \mathrm{~m}$ de altitude. O delineamento experimental adotado em cada localidade foi blocos ao acaso, com quatro repetições e, tratamentos constituídos por três épocas de plantio: abril (outono), julho (inverno) e setembro (primavera). Após a colheita das raízes tuberosas avaliou-se $\mathrm{pH}$, teores de acidez total titulável, umidade, sólidos solúveis, glicídios redutores, fibra bruta e cinzas, além de, cor, dureza (força máxima registrada no primeiro ciclo de penetração ou compressão) e índice de mastigabilidade (energia requerida para mastigar o alimento, dada por gomosidade $\mathrm{x}$ elasticidade). As raízes tuberosas cultivada em $837 \mathrm{~m}$ de altitude, independente da época de plantio, apresentaram maiores teores de sólidos solúveis e suco mais claro, conferindo melhor qualidade. Entretanto, quando cultivada em $113 \mathrm{~m}$ de altitude, os plantios de abril a julho proporcionaram melhor qualidade da raíz por apresentar menor dureza e suco mais claro.

Palavras-chave: Smallanthus sonchifolius, qualidade pós-colheita, coloração instrumental, características sensoriais.

\section{Received on March 17, 2017; accepted on February 9, 2018}

$\mathbf{I}_{n}^{\mathrm{n}}$ the last years, besides having nutritional function and providing sensory appeal, food should also provide a third function which is related to a specific physiological response produced by, what is called, functional foods (Zeraik et al., 2010).

Tuberous roots of yacon (Smallanthus sonchifolius) are described as the functional food with higher content of fructooligosaccharides (FOS) in nature (Santana \& Cardoso, 2008) and its consumption has provided medicinal effects on chronic disease control, such as diabetes, blood pressure and cholesterol levels (Oliveira et al., 2013). Besides, yacon roots are considered a fiber-rich prebiotic food (Quinteros, 2000). The consumption can be in natura, juice or derived products, like syrup, flour, jelly, functional drink based on yacon, among others (Borges et al., 2012).

Other main components of yacon tuberous roots are water and other carbohydrates such as sucrose, fructose and glucose. Root water content ranges from $83 \%$ to $90 \%$, which characterizes yacon as a highly perishable as well as a low calorie food (1.0-1.5 kcal g-1). It has low ash contents and the minerals present in this vegetable are calcium, phosphorus, magnesium, sodium, iron and, most importantly, potassium.
Yacon presents relatively low levels of proteins, lipids and vitamins (Santana \& Cardoso, 2008); it also contains phenolic compounds, such as chlorogenic and caffeic acid, flavonoids and other antioxidant substances (Castro et al., 2012).

Due to its characteristics as functional food, its consumption has been stimulated, representing a new product to be exploited and applied to social, agricultural, technological and scientific levels (Borges et al., 2012; Gusso et al., 2015). However, variations in physical and chemical compositions of yacon tuberous roots were verified in studies involving 
cultivation and processing of this root in different countries (Herman et al., 1999; Quinteros, 2000; Vasconcelos et al., 2010). The authors believe that besides the differences of inputs and cultural practices used in yacon cultivation, these variations may be related to altitudes and planting times in which yacon is grown, considering that optimal development of yacon occurs at temperature between 18 and $25^{\circ} \mathrm{C}$, and low evening temperature seems to be necessary to form tuberous roots properly (Seminario et al., 2003).

Given the above, the aim of this study was to determine physico-chemical characteristics of yacon tuberous roots at different altitudes and planting times.

\section{MATERIAL AND METHODS}

The experiment was installed in two growing altitudes, in Ibatiba-ES [201 $17^{\prime} \mathrm{S}, 41^{\circ} 37^{\prime} \mathrm{W}$, altitude $837 \mathrm{~m}$ (high altitude)], in Alegre-ES [20 $45^{\prime} \mathrm{S}$, $41^{\circ} 29^{\prime} \mathrm{W}$, altitude $113 \mathrm{~m}$ (low altitude)], from April, 2013 to April, 2014.

The local climate in the South of Espírito Santo is Aw, with two welldefined seasons along the year, rainy summer between October and March and dry winter from April to September; average annual temperature of $23^{\circ} \mathrm{C}$, and annual rainfall around 1,200 $\mathrm{mm}$ (Pezzopane et al., 2012).

Rainfall and monthly average temperature, maximum and minimum, were collected at the closest automatic weather station, INMET in AlegreES $\left(20^{\circ} 21^{\prime} \mathrm{S} ; 41^{\circ} 33^{\prime} \mathrm{W} ; 758 \mathrm{~m}\right.$ altitude), INCAPER, located in the municipality of Iúna-ES. Between April and September, 2013, in Iúna, the accumulated rainfall was $252.2 \mathrm{~mm}$ and average temperatures, maximum and minimum, were 24.58 and $14.00^{\circ} \mathrm{C}$, respectively. In Alegre, accumulated rainfall was $229.2 \mathrm{~mm}$ and average temperatures, maximum and minimum, were 28.38 and $16.92^{\circ} \mathrm{C}$, respectively. Between October, 2013 and April, 2014, in Iúna, accumulated rainfall was $1,021.2 \mathrm{~mm}$ and average temperatures, maximum and minimum, were 27.73 and $17.50^{\circ} \mathrm{C}$, respectively. In Alegre, accumulated rainfall was $1,162.6 \mathrm{~mm}$ and average temperatures, maximum and minimum, were 31.89 and $20.43^{\circ} \mathrm{C}$, respectively.

Soils, in both places, were classified as Typic Hapludox, medium texture (Embrapa, 2014) and base saturation (V) 46.6\%. At high and low altitudes, respectively, the authors also observed the values of $\mathrm{pH}=6.20$ and $6.37 ; \mathrm{P}=54$ and $37 \mathrm{mg} \mathrm{dm}^{-3} ; \mathrm{K}=80$ and $57 \mathrm{mg} \mathrm{dm}^{-3}$; $\mathrm{Ca}=2.12$ and $1.50 \mathrm{cmol}_{\mathrm{c}} \mathrm{dm}^{-3}$; and $\mathrm{Mg}=$ 0.87 and $0.71 \mathrm{cmol}_{\mathrm{c}} \mathrm{dm}^{-3}$.

In each locality, the experimental design was randomized blocks, with four replicates. The treatments consisted of three planting times in 2013: April (autumn), July (winter) and September (spring).

At full flowering (over $80 \%$ of the stand), harvest at high altitude, was performed as follows: a) planting date on April 2013, harvested after 270 days, on January 2014; b) planting date on July 2013, harvested after 240 days, on March 2014; c) planting date on September 2013, harvested after 180 days, on March 2014. At low altitude, harvests were performed as follows: a) planting date on April 2013, harvested after 240 days, on December 2013; b) planting date on July 2013, harvested after 180 days, on January 2014; c) planting date on September 2013, harvested after 210 days, on April 2014; the experimental unit consisted of five 4-m plant rows, spacing $1.0 \mathrm{~m}$ between rows and $0.5 \mathrm{~m}$ between plants, totalizing 8 yacon plants per plant row. However, only the tuberous roots harvested in the useful area, represented by the central $5 \mathrm{~m}^{2}$ of each plot, were used for evaluations.

In each place, soil was plowed 30 cm deep and, then, harrowed. Tanned bovine manure was applied at the dose of $180 \mathrm{~g}$ per plant. Bovine manure showed the following nutrients: $\mathrm{N}=$ $14.21 \mathrm{~g} \mathrm{~kg}^{-1} ; \mathrm{P}=4.75 \mathrm{~g} \mathrm{~kg}^{-1} ; \mathrm{K}=5.28$ $\mathrm{g} \mathrm{kg}^{-1} ; \mathrm{Ca}=4.29 \mathrm{~g} \mathrm{~kg}^{-1}$ and $\mathrm{Mg}=1.92$ $\mathrm{g} \mathrm{kg}^{-1}$. Rhizophores of approximately 35 grams were planted in furrows at 10 cm depth, in the desired spacing. During growing cycle, spontaneous plants were controlled and sprinkler irrigation was performed weekly, using $30 \mathrm{~mm}$ of water depth, split into two applications, mainly in the months of lower rainfall (June, July, August and September, 2013 and January and February, 2014).

Tuberous roots were harvested and sent to Laboratório de Química de Alimentos of UFES, where they were washed and sanitized. In order to analyze moisture, $100 \mathrm{~g}$ of fresh roots, previously peeled and chopped into chips, were weighed. This material was taken into a dryer under forced air circulation at $65^{\circ} \mathrm{C}$ until reaching constant mass. Moisture content was determined based on the difference between initial and final dry mass (Instituto Adolfo Lutz, 2008). After moisture determination, dry roots were crushed and crude fiber content determined in accordance with AOCS method 18 (2003), using fiber digester Marconi MA-444/CI. Fresh roots were incinerated in muffle at $550^{\circ} \mathrm{C}$, to obtain ash content (Instituto Adolfo Lutz, 2008).

Then, part of roots was peeled, chopped into slices, and put into a domestic juice extractor device. After extraction, juice was filtered and submitted to analyses: $\mathrm{pH}$, titratable total acidity, soluble solids, reducing sugars and color (Instituto Adolfo Lutz, 2008).

The $\mathrm{pH}$ was determined with the aid of a benchtop pH meter (Ion pHB500). Titratable total acidity was determined putting a 5-g aliquot of juice into a $125 \mathrm{~mL}$ Erlenmeyer flask, in which the authors added $50 \mathrm{~mL}$ of water and 2 to 4 drops of phenolphthalein solution, titrated with $0.01 \mathrm{~mol} / \mathrm{mL}$ sodium hydroxide solution up to pink coloration. Soluble solid content was determined using a digital bench refractometer (Atago Abber DR-A1). Reducing sugar content was determined by transferring $5-\mathrm{g}$ aliquot of juice into a $100-\mathrm{mL}$ volumetric flask, in which the authors added $100 \mathrm{~mL}$ of distilled water until complete the volume and, transferred to a burette. In a 250-mL flat bottom flask, each of the Fehling solution, A and B, were transferred with the aid of $10-\mathrm{mL}$ pipettes, and, then, $40 \mathrm{~mL}$ of water was added. The solution was heated on electric plates and shaken until boiling and drops of the burette solution were added into the boiling solution until this solution went from blue to colorless. The same steps were performed for 
standard glucose solution.

Immediately after the juice extraction, color coordinates were determined according to CIELAB chart for colors, using color coordinates $\mathrm{L}^{*}$, $\mathrm{a}^{*}$ and $\mathrm{b}^{*}$, in which coordinate $\mathrm{L}^{*}$ is related to luminosity $(0=$ black and $100=$ white), coordinate $a^{*}$ positive tending to red, $a^{*}$ negative tending to green and $b^{*}$ positive tending to yellow and $b^{*}$ negative tending to blue (Hunterlab, 2000). Color was analyzed by using reflectance and transmittance spectrophotometry (Konica-Minolta CM-5).

Fresh root texture was determined using a Brookfield CT3 Texture Analyzer. The computer software TexturePro CT v1.4 build 17 (Windows NT 6.1 - Build 7601: Service Pack 1) was used to collect data. The device was programmed to measure directly texture: hardness and chewiness. To perform this analysis, probe TA 39 (2-mm diameter and 20-mm length) was used. Root samples were previously selected in standard sizes (5-cm diameter) and chopped (5-cm thickness). The used parameters were: pre-test speed $=2.0$ $\mathrm{mm} / \mathrm{s}$; test speed $=2.0 \mathrm{~mm} / \mathrm{s}$; post-test speed $=2.0 \mathrm{~mm} / \mathrm{s} ;$ and distance $=5 \mathrm{~mm}$.

Obtained data were submitted to joint analysis of variance (ANOVA) involving the two growing altitudes, 837 and $113 \mathrm{~m}$, using $\mathrm{F}$ test at 5\% probability, and average comparison using Tukey test at $5 \%$ probability. Statistical analyses were done using computer program Genes (Cruz, 2006).

\section{RESULTS AND DISCUSSION}

Any significant differences for $\mathrm{pH}$ values and color coordinate $b^{*}$ of the extracted juice of yacon tuberous roots was noticed (Table 1). Titratable total acidity did not also range among planting times, at both growing altitudes. These results denote that yacon root flavor, slightly acidic (inferior $\mathrm{pH}$, but close to 7), and the influence of yellow color (b* positive) in the juice extracted from these roots, were similar, it means, they are related to growing and planting time.

The $\mathrm{pH}$ values of the yacon tuberous roots juice ranged from 6.57 to 6.83 (Table 1). These values, close to neutrality, presented low titratable total acidity contents, between 0.071 and $0.088 \%$ (Table 1), similar to the values verified by Prati et al. (2009) and Castro et al. (2013). These results allow characterizing yacon as a low acidity food and, consequently, more susceptible to deterioration by microorganisms (Braga et al., 2013). Yacon roots kept similar $\mathrm{pH}$ values, however, titratable total acidity of the roots grown at 837 $\mathrm{m}$ altitude was lower (Table 1), since a greater quantity of organic acids had been used as carbon source for sugar synthesis (Awad, 1993), corroborating the higher soluble solid contents (Table 2 ). These results suggest that yacon produced at $113 \mathrm{~m}$ altitude shows higher content of antioxidants, such as chlorogenic acid, ferulic acid and caffeic acid (Simonovska et al., 2003) than the yacon plant produced at 837 $\mathrm{m}$ altitude. Comparing with other roots and tubers, yacon has high quantity of phenolic compounds, about $200 \mathrm{mg} 100$ $\mathrm{g}^{-1}(0.2 \%)$ of edible part (fresh mass), considering the chlorogenic acid present in $48.5 \pm 12.9 \mu \mathrm{g} \mathrm{g}^{-1}$ of fresh pulp in an experiment conducted by Valentová \& Ulrichová (2003).

Root moisture contents were close, between 88.86 and $91.21 \%$, however, statistic difference occurred in relation to a low variation coefficient (Table 1). This high moisture content contributes positevely to its low energetic value (Santana \& Cardoso, 2008). On the other hand, it reduces in a significant way its shelf life in non-refrigerated conditions (Scher et al., 2009). In relation to growing altitudes, the roots produced at $113 \mathrm{~m}$ altitude showed higher moisture content (Table 1) corroborating the lower soluble solid content (Table 2). Considering planting times, independent of altitude, higher moisture contents was noticed in roots planted in April (Table 1), probably due to higher soil moisture in the rainy planting season (summer), favoring water absorption.

Root soluble solid contents ranged from 8.58 to $13.6^{\circ}$ Brix (Table 2), values similar to the ones verified in other researches (Quinteros, 2000; Prati et al., 2009; Lago et al., 2011). Planting in September, at both altitudes, provided higher soluble solid content, however, independent of planting season, the roots produced at $837 \mathrm{~m}$ altitude showed superior average comparing to the ones produced at $113 \mathrm{~m}$ altitude (Table 2), probably due to warmer temperatures at higher altitudes, which contribute to lower root respiratory rates and, consequently, lower carbohydrates consumption. Morevoer, yacon was described as neutral to photoperiod for formation of stems and roots (Seminario et al., 2003), warmer temperatures may also contribute to more efficient tuberization process (Rodríguez-Falcón et al., 2006) and lower occurrence of photorespiration (Kerbauy, 2013), favoring carbohydrates transportation from leaves to tuberous roots. The authors highlight that lower moisture content produced at $837 \mathrm{~m}$ altitude (Table 1) could also contribute, thus being the soluble solids more concentrated or less diluted.

The observed results suggest that yacon produced at $837 \mathrm{~m}$ altitude, mainly planting in September, may show greater market acceptance in natura for its sweetness, since higher soluble solid contents were verified (Table $2)$. Due to high positive correlation $(r=0.84)$ between soluble solid and fructooligosaccharides (FOS) contents (Hermann et al., 1999), roots produced at this altitude may present higher contents of this carbohydrate, which has aroused many researchers' and also food industry interest as this is a bioactive component with prebiotic claim and stable to most food industry processes (Borges et al., 2012).

Reducing sugar contents ranged from 3.43 to $5.36 \%$ (Table 2), values similar to the ones verified by Prati et al. (2009), 3.94\%, and lower than the ones obtained by Lago et al. (2011) in yacon juice presenting soluble solid concentration of $10^{\circ}$ Brix, considering that $7.8 \%$ for glucose and $16.42 \%$ for fructose. In average, growing altitude did not influence on reducing sugar contents, however, the authors noticed differences in relation to planting time at each altitude. Lower reducing sugar contents were verified in roots planted in July, at $837 \mathrm{~m}$ altitude, and in April at $113 \mathrm{~m}$ altitude, corroborating lower 
soluble solid contents (Table 2). Some studies demonstrated changes in sugar chemical composition of yacon roots after harvest: polymerized sugars tend to depolymerize as time goes on, it means, FOS are hydrolyzed to simple sugars by the action of fructan hydrolase enzyme, which converts them to fructose, sucrose and glucose. Nevertheless, this conversion is slower on roots stored under refrigeration temperatures (Graefe et al., 2004).

Crude fiber content ranged from 13.38 to $28.49 \%$, on dry basis (Table 2 ), values lower than the ones found by Vasconcelos et al. (2010) (33.15\%).

Table 1. Physical and chemical characteristics of yacon tuberous roots grown at different altitudes and planting times. Ibatiba/Alegre, UFES, 2013/14.

\begin{tabular}{lcccc}
\hline Growing altitude & $\mathbf{p H}$ & $\begin{array}{c}\text { Acidity }^{2} \\
(\mathbf{\%})\end{array}$ & $\begin{array}{c}\text { Moisture } \\
\mathbf{( \% ,}, \mathbf{b u})\end{array}$ & $\mathbf{b}^{* 3}$ \\
\hline $837 \mathrm{~m}$ & $6.78 \mathrm{a}^{1}$ & $0.071 \mathrm{~b}$ & $88.96 \mathrm{~b}$ & $42.88 \mathrm{a}$ \\
$113 \mathrm{~m}$ & $6.66 \mathrm{a}$ & $0.088 \mathrm{a}$ & $90.40 \mathrm{a}$ & $38.72 \mathrm{a}$ \\
\hline Planting time & & & & \\
\hline April & $6.83 \mathrm{a}^{1}$ & $0.076 \mathrm{a}$ & $91.21 \mathrm{a}$ & $41.90 \mathrm{a}$ \\
July & $6.76 \mathrm{a}$ & $0.076 \mathrm{a}$ & $88.86 \mathrm{~b}$ & $44.07 \mathrm{a}$ \\
September & $6.57 \mathrm{a}$ & $0.086 \mathrm{a}$ & $88.97 \mathrm{~b}$ & $36.43 \mathrm{a}$ \\
\hline CV $(\%)$ & 4.05 & 9.49 & 0.73 & 10.35 \\
\hline
\end{tabular}

${ }^{1}$ Averages followed by same letters, vertically, do not differ by $\mathrm{F}$ test for growing altitudes, and Tukey for planting times, both at $5 \%$ probability; ${ }^{2}$ Acidity expressed in $\%$ malic acid; ${ }^{3}$ Coordinate $b^{*}$ color.

Table 2. Chemical characteristics of yacon tuberous roots grown at different altitudes and planting times. Ibatiba/Alegre, UFES, 2013/14.

\begin{tabular}{|c|c|c|c|c|}
\hline \multirow{3}{*}{ Planting time } & \multicolumn{4}{|c|}{ Growing altitudes (m) } \\
\hline & 837 & 113 & 837 & 113 \\
\hline & \multicolumn{2}{|c|}{ Soluble solids ( $\left.{ }^{\circ} \mathrm{Brix}\right)$} & \multicolumn{2}{|c|}{ Reducing sugar $(\% \mathrm{~m} / \mathrm{m})$} \\
\hline April & $12.30 \mathrm{~b}$ & $8.58 \mathrm{c}$ & $4.84 \mathrm{a}$ & $3.43 \mathrm{~b}$ \\
\hline July & $11.33 \mathrm{c}$ & $9.25 \mathrm{~b}$ & $4.16 \mathrm{~b}$ & $5.36 \mathrm{a}$ \\
\hline September & $13.60 \mathrm{a}$ & $11.65 \mathrm{a}$ & $4.91 \mathrm{a}$ & $4.89 \mathrm{a}$ \\
\hline Averages $^{1}$ & $12.41 \mathrm{~A}$ & $9.83 \mathrm{~B}$ & $4.64 \mathrm{~A}$ & $4.56 \mathrm{~A}$ \\
\hline \multirow[t]{2}{*}{$\mathrm{CV}(\%)$} & \multicolumn{2}{|c|}{2.34} & \multicolumn{2}{|c|}{7.91} \\
\hline & \multicolumn{2}{|c|}{ Crude fiber (\% bs) } & \multicolumn{2}{|c|}{ Ashes (\% bu) } \\
\hline April & $28.49 \mathrm{a}$ & $21.30 \mathrm{~b}$ & $0.25 \mathrm{a}$ & $0.36 \mathrm{~b}$ \\
\hline July & $19.68 \mathrm{~b}$ & $25.68 \mathrm{a}$ & $0.16 \mathrm{~b}$ & $0.35 \mathrm{~b}$ \\
\hline September & $19.20 \mathrm{~b}$ & $13.38 \mathrm{c}$ & $0.23 \mathrm{a}$ & $0.55 \mathrm{a}$ \\
\hline Averages $^{1}$ & $22.46 \mathrm{~A}$ & $20.12 \mathrm{~A}$ & $0.21 \mathrm{~B}$ & $0.42 \mathrm{~A}$ \\
\hline $\mathrm{CV}(\%)$ & \multicolumn{2}{|c|}{8.99} & \multicolumn{2}{|c|}{8.54} \\
\hline
\end{tabular}

${ }^{1}$ Horizontally, compare averages between the growing altitudes for each variable, where same capital letters do not differ by $\mathrm{F}$ test at $5 \%$ probability; ${ }^{2}$ Vertically, averages of planting times within each growing altitude followed by same lowercase letters do not differ by Tukey test at $5 \%$ probability.
November, 2013 (maximum average temperature over $30^{\circ} \mathrm{C}$ ), was prejudicial to plant development, tuberization process, and, consequently, crude fiber accumulation by the roots.

Yacon tuberous roots of this study, independent of altitude and planting time, showed crude fiber contents (in dry basis) high enough to be considered a fiber-rich food (Quinteros, 2000). This high content makes yacon a fiber-rich food supplement, as pointed out by Vasconcelos et al. (2010), producing flour from this root, they verified a percentual composition of 47.42 and $12.21 \%$ bs of crude fiber, respectively.

Ash contents in natura ranged from 0.16 to $0.55 \%$, on wet basis (Table 2), being directly related to accumulation of minerals, such as calcium, phosphorus, magnesium, sodium, iron and, mainly, potassium ( $230 \mathrm{mg} 100 \mathrm{~g} \mathrm{~g}^{-1}$ fresh edible mass or 1 to $2 \%$ dry mass), which is present in great quantities in fruits which are generally consumed in Brazil, just like bananas, oranges, lemons, guavas, apples, papayas, watermelons, melons, pears, among others (Rodrigues et al., 2011). The highest average ash content occurred in the roots produced at 113 $\mathrm{m}$ altitude, nevertheless, planting in September, the average was significantly higher than the ones planted in April and July, which did not differ among them (Table 2). The highest temperatures at $113 \mathrm{~m}$ altitude, mainly during the cultivation cycle of yacon planted in September, may have contributed to an increase in plant transpiration rate, favoring nutrient absorption by the roots, and also for a photorespiration increase, decreasing efficiency of photosynthesis (Kerbauy, 2013). Thus, most of the nutrients were not assimilated and translocated to the plant shoot, corroborating higher ash content in roots produced at $113 \mathrm{~m}$ altitude (Table 2). At $837 \mathrm{~m}$ altitude, the authors could also notice a difference in ash contents in the roots, however, showing less discrepancy between planting times, being greater when planting in April and September, which did not differ among them, and less in the planting of July (Table 2).

In general, the samples showed moderate luminosity $\left(\mathrm{L}^{*}\right)$ (average 
of 38.00), with the predominance of the yellow component ( $b^{*}$ positive) (average of 40.80) over the red component ( $\mathrm{a}^{*}$ positive) (average of 3.72), which contribution in color was little showing quite low values, showing yellowish juice color extracted from yacon tuberous roots (Tables 1 and 3 ). In Brazil, yacon tuberous roots generally show light yellow or intense yellow colors, being the carotenoids, pigments responsible for the yellow, orange and red coloring of vegetables, in addition to some of them being precursors of vitamin A (Quinteros, 2000).

Roots produced at $837 \mathrm{~m}$ altitude provided lighter juices (higher L* average) and with less influence of red color (lower $b^{*}$ average) comparing to roots produced at $113 \mathrm{~m}$ altitude (Table 3). At $837 \mathrm{~m}$ altitude, the influence of these two color coordinates was similar at planting times. On the other hand, at $113 \mathrm{~m}$ altitude, the roots planted in September provided a darker juice (lower $\mathrm{L}^{*}$ ) and with less influence of red color (lower $b^{*}$ ) comparing with the roots planted in April and July (Table 3). This less influence of red color occurred due to high temperature during growing cycle of planting in September at this altitude, considering that above $30^{\circ} \mathrm{C}$ inhibition of the synthesis of lycopene, carotenoid responsible for the red coloration in vegetables occurs without affecting $\beta$-carotene, responsible for yellow coloration (Awad, 1993). Darker color of juices extracted from the roots grown at $113 \mathrm{~m}$ altitude, mainly considering planting in spring can be related to their higher acidity (Table 1), since darkening reactions are caused by polyphenoloxidase and peroxidase enzymes, and the presence of phenolic compounds, such as chlorogenic and caffeic acids, make yacon roots more susceptible to these reactions (Seminario et al., 2003). These results suggest that yacon juice from roots planted in September, at $113 \mathrm{~m}$ altitude, has lower market acceptance due to its darker color, which contributes to a worse product appearance.

In relation to atributes concerning texture, similar values (average) for hardness (force required to deform them), were noticed among the roots produced at 837 and $113 \mathrm{~m}$ altitude (Table 3). However, roots grown at 837 $\mathrm{m}$ altitude showed higher chewing rate (energy required to disintegrate them into a ready-to-swallow state), probably in relation to a lower moisture content (Table 1) and, consequently, higher dry

Table 3. Coordinates $\mathrm{L}^{*}$ and $\mathrm{a}^{*}$ of color scale and texture profile of yacon tuberous roots grown at different altitudes and planting times. Ibatiba/Alegre, UFES, 2013/14.

\begin{tabular}{|c|c|c|c|c|}
\hline \multirow{3}{*}{ Planting time } & \multicolumn{4}{|c|}{ Growing altitudes (m) } \\
\hline & 837 & 113 & 837 & 113 \\
\hline & \multicolumn{2}{|c|}{$\mathbf{L}^{*}$} & \multicolumn{2}{|c|}{$a^{*}$} \\
\hline April & $40.24 \mathrm{a}$ & $36.64 \mathrm{a}$ & $2.93 \mathrm{a}$ & $7.17 \mathrm{a}$ \\
\hline July & $43.38 \mathrm{a}$ & $39.29 \mathrm{a}$ & $2.94 \mathrm{a}$ & $5.05 \mathrm{~b}$ \\
\hline September & $43.78 \mathrm{a}$ & $24.64 \mathrm{~b}$ & $3.22 \mathrm{a}$ & $0.99 \mathrm{c}$ \\
\hline Averages $^{1}$ & $42.46 \mathrm{~A}$ & $33.53 \mathrm{~B}$ & $3.03 \mathrm{~B}$ & $4.40 \mathrm{~A}$ \\
\hline \multirow[t]{2}{*}{$\mathrm{CV}(\%)$} & \multicolumn{2}{|c|}{8.94} & \multicolumn{2}{|c|}{18.04} \\
\hline & \multicolumn{2}{|c|}{ Hardness $^{3}$ (g) } & \multicolumn{2}{|c|}{ Chewing index ${ }^{4}(\mathrm{~g})$} \\
\hline April & $474.08 \mathrm{a}$ & $448.17 \mathrm{~b}$ & $33.83 \mathrm{a}$ & $14.08 \mathrm{~b}$ \\
\hline July & $490.00 \mathrm{a}$ & $458.67 \mathrm{~b}$ & $19.08 \mathrm{~b}$ & $11.42 \mathrm{~b}$ \\
\hline September & $484.25 \mathrm{a}$ & $775.00 \mathrm{a}$ & $24.25 \mathrm{~b}$ & $32.42 \mathrm{a}$ \\
\hline Averages $^{1}$ & $482.78 \mathrm{~A}$ & $560.61 \mathrm{~A}$ & $25.72 \mathrm{~A}$ & $19.31 \mathrm{~B}$ \\
\hline $\mathrm{CV}(\%)$ & \multicolumn{2}{|c|}{11.52} & \multicolumn{2}{|c|}{14.50} \\
\hline \multicolumn{5}{|c|}{$\begin{array}{l}{ }^{1} \text { Horizontally, compare averages between the growing altitudes for each variable, where the } \\
\text { same capital letters do not differ by } \mathrm{F} \text { test at } 5 \% \text { probability; }{ }^{2} \text { Vertically, averages of planting } \\
\text { times within each growing altitude followed by the same lowercase letters do not differ by } \\
\text { Tukey test at } 5 \% \text { probability; }{ }^{3} \text { Hardness is the maximum force recorded of the first cycle of } \\
\text { penetration or compression. It is related to the breaking strength of the material; }{ }^{4} \text { Chewiness } \\
\text { index is the energy required to chew food: gumminess x elasticity. }\end{array}$} \\
\hline
\end{tabular}

mass content. At $837 \mathrm{~m}$ altitude, similar hardness values occurred among roots planted in different planting times, however, planting in April promoted higher chewing rate (Table 3 ) in relation to their higher ash and crude fiber contents (Table 2), whereas roots planted in winter and spring did not differ among them (Table 3). At $113 \mathrm{~m}$ altitude, roots planted in September showed quite significantly higher values of hardness and chewing rate, in relation to ash contents, which were also significantly high (Table 2), when comparing with roots planted in April and July, which did not differ among them (Table 3). The authors highlight that hardness of roots planted in September at $113 \mathrm{~m}$ altitude was above $60 \%$ higher than the average of roots in other treatments.

Texture, appareance and flavor are the three quality attributes which establish food acceptance by the consumer (Mohsenin, 1986). Thus, the authors concluded that yacon tuberous roots produced at $837 \mathrm{~m}$ altitude, independent of planting time, showed higher soluble solid contents and lighter juice, resulting in a better root quality. Nevertheless, roots produced at $113 \mathrm{~m}$ altitude, the plantings in April and July provided better quality of yacon since it presents less hardness and lighter juice.

\section{ACKNOWLEDGEMENTS}

To Coordination of Improvement of Higher Education Personnel (CAPES) for the doctorate scholarship of the first author of this study. To FAPES for capixaba researcher scholarship of the third and fourth authors of this study. To CNPq (The National Council for Scientific and Technological Development) and FAPES for the financial support for this research.

\section{REFERENCES}

AMERICAN OIL CHEMISTS SOCIETY (AOCS). 2003. Oficial and recommended practices-method $18.5^{\text {th }}$. ed. Second printing. Bc 6- 49

AWAD, M. 1993. Fisiologia pós-colheita de frutos. São Paulo: Nobel.

BORGES, JTS; PIROZI, MR; PAULA, CD; 
VIDIGAL, JG; SILVA, NAS; CALIMAN, FRB. 2012. Yacon na alimentação humana: aspectos nutricionais, funcionais, utilização e toxicidade. Scientia Amazonia 1: 3-16.

BRAGA, TR; PEREIRA, RA; SILVEIRA, MRS; SILVA, LR; OLIVEIRA, MMT. 2013. Caracterização físico-química de progênies de pimentas (Capsicum frutescens L.). Revista de la Facultad de Agronomía 112: 6-10.

CASTRO, A; CABALLERO, M; HERBAS, A; CARBALlO, S. 2012. Antioxidants in yacon products and effect of long term storage. Ciência e Tecnologia de Alimentos 32: 432-435.

CASTRO, A; CÉSPEDES, G; CARBALLO, S; BERGENSTAHL, B; TORNBERG, E. 2013. Dietary fiber, fructooligosaccharides, and physicochemical properties of homogenized aqueous suspensions of yacon (Smallanthus sonchifolius). Food Research International 50: $392-400$

CRUZ, CD. 2006. Programa Genes: Biometria. Viçosa: UFV. 382p.

EMBRAPA. 2014. Sistema Brasileiro de Classificação de Solos. 4.ed. Rio de Janeiro: Embrapa Solos. 377p.

GUSSO, AP; MATTANNA, P; RICHARDS, N. 2015. Yacon: benefícios à saúde e aplicações tecnológicas. Ciência Rural 45: 912-919.

GRAEFE, S; HERMANN, M; MANRIQUE, I; GOLOMBEK, S; BUERKERT, A. 2004. Effects of post-harvest treatments on the carbohydrate composition of yacon roots in the Peruvian Andes. Field Crops Research 86: $157-165$

HERMANN, M; FREIRE, I; PAZOS, C. 1999. Compositional diversity of the yacon storage root. In: Impact on a changing world: Program report 1997-98. Lima: CIP. p. 425-432.

HUNTERLAB. 2000. What is color and how is measured. Applications Note 12: 1-8.

INSTITUTO ADOLFO LUTZ. 2008. Métodos fisico-químicos para análise de alimentos.
4 ed. (1 $1^{\text {a }}$ ed. digital). São Paulo: IAL. 1002p.

KERBAUY, G. 2013. Fisiologia Vegetal. 2. ed. Rio de Janeiro: Guanabara Koogan. 431p.

LAGO, CC; BERNSTEIN, A; BRANDELLI, A; NOREÑA, CZ. 2011. Characterization of powdered yacon (Smallanthus sonchifolius) juice and pulp. Food and Bioprocess Technology 5: 2183-2191.

MOHSENIN, NN. 1986. Physical properties of plant and animal materials: structure, physical caracteristics and mechanical properties. $2^{\mathrm{a}}$ ed. Canadá: Gordon and Breach Publishers. 891p.

OLIVEIRA, GO; BRAGA, CP; FERNANDES, AAH. 2013. Improvement of biochemical parameters in type 1 diabetic rats after the roots aqueous extract of yacon (Smallanthus sonchifolius). Food and Chemical Toxicology 59: 256-260.

PEZZOPANE, JEM; CASTRO, FS; PEZZOPANE, JRM; CECÍLIO, RA. 2012. Agrometeorologia: aplicações para o Espírito Santo. Alegre: CAUFES. $174 \mathrm{p}$.

PRATI, P; BERBARI, SAG; PACHECO, MTB; SILVA, MG; NACAZUME, N. 2009. Estabilidade dos componentes funcionais de geleia de yacon, goiaba e acerola, sem adição de açúcares. Brazilian Journal of Food Technology 12: 285-294.

QUINTEROS, ETT. 2000. Produção com tratamento enzimático e avaliação do suco de yacon. Campinas: Universidade Estadual de Campinas 163p (Tese doutorado).

RODRIGUES, FC; CASTRO, ASB; MARTINO, HSD; FERREIRA, CLLF. 2011. Farinha de yacon (Smallanthus sonchifolius): produção e caracterização química. Revista do Instituto Adolfo Lutz 70: 290-295.

RODRÍGUEZ-FALCÓN, M; BOU, J; PRAT, S. 2006. Seasonal control of tuberization in potato: conserved elements with the flowering response. Annual Review of Plant Biology 57: 151-180.
SANTANA, I; CARDOSO, MH. 2008. Raiz tuberosa de yacon (Smallanthus sonchifolius): potencialidade de cultivo, aspectos tecnológicos e nutricionais. Ciência Rural 38: 898-905.

SANTOS, CG; AMARAL, PNC; CARPEJAN, GC; JUNGES, L. 2014. Produção de silagem de milho híbrido com diferentes idades de corte. Revista Científica de Produção Animal 16: 32-45.

SEMINARIO, J; VALDERRAMA, M; MANRIQUE, I. 2003. El yacon: fundamentos para el aprovechamiento de un recurso promisorio. Lima: CIP, Universidad Nacional de Cajamarca, Agencia Suiza para el Desarrollo y la Cooperación (COSUDE). 60p.

SIMONOVSKA, B; VOVK, I; ANDRENSEK, S; VALENTOVA, K; ULRICHOVA, J. 2003. Investigation of phenolic acids in yacon (Smallanthus sonchifolius) leaves and tubers. Journal of Chromatography A, 1016: 89-98.

SCHER, CF; RIOS, AO; NOREÑA, CPZ. 2009. Hot air drying of yacon (Smallanthus sonchifolius) and its effect on sugar concentrations. International Journal of Food Science and Tecnology 44: 2169-2175.

VASCONCELOS, CM; SILVA, CO; TEIXEIRA, LJQ; CHAVES, JBP; MARTINO, HSD. 2010. Determination of the soluble dietary fiber fraction in yacon (Smallanthus sonchifolius) root and flour by enzymaticgravimetric method and high pressure liquid chromatography. Revista do Instituto Adolfo Lutz 69: 188-193.

VALENTOVÁ, K; ULRICHOVÁ, J. 2003. Smallanthus sonchifolius and Lepidium meyenii - prospective Andean crops for the prevention of chronic diseases. Biomedical Papers 147: 119-130.

ZERAIK, ML; PEREIRA, CAM; ZUIN, VG; YARIWAKE, JH. 2010. Maracujá: um alimento funcional? Revista Brasileira de Farmacologia 20: 459-471. 